\title{
Morphological evolution of the porous silicon surface for different etching time and current density in HF-ethanol solution
}

\section{Evolução morfológica da surperfície do silício poroso por diferente tempo de ataque e densidade de corrente em solução HF-etanol}

Miguel Angelo do Amaral Junior ${ }^{1}$, Belchior Elton Lima da Silva ${ }^{1}$, Neidenêi Gomes Ferreira ${ }^{1}$,

Antonio Fernando Beloto ${ }^{1}$, Maurício Ribeiro Baldan

\section{ABSTRACT}

Porous silicon samples were obtained by anodization process of a n-type silicon wafer. The pores formations were investigated by varying the electrochemical parameters like as current density and etching time. The main objective of the present study is to investigate the influence of these parameters in order to increase the surface area of the porous layer. Scanning electron microscopy and optical profilometer were used for morphological characterization, such as pore size, surface area and morphological evolution of the porous layer. The pores shape showed a tendency to be circular and then break with the increase of etching time as well as current density, resulting in a complex morphological with large surface area. In this work we were obtained surface area increases up to $185 \%$. This information will be useful for future applications destined for material requiring high surface area, such as biosensor, gas sensor and substrate for film

Keywords: Porous silicon; Morphological evolution; Surface area.

\section{RESUMO}

As amostras de silício poroso foram obtidas por processo de anodização das lâminas de silício tipo-n. As formações de poros foram investigadas variando os parâmetros eletroquímicos, tais como, densidade de corrente e tempo de ataque. O principal objetivo deste estudo é investigar a influência dos parâmetros eletroquímico para aumentar a área superficial da camada porosa. Microscópio eletrônico de varredura e perfilômetro óptica foram utilizados para caracterização morfológica da superfície, tais como, tamanho do poro, área superficial e evolução morfológica da camada porosa. O formato dos poros mostrou uma tendência a ser circulares e então quebrar com o aumento do tempo de ataque bem como a densidade de corrente, resultando em uma morfologia complexa com grande área superficial. Neste trabalho foram obtidos resultados com aumento de área superficial de até $185 \%$. Este resultado será útil para futuras aplicações destinadas a materiais que necessitam de alta área superficial, tais como sensores biológicos, sensores de gás e substrato para filme.

Palavras-chave: Silício poroso; Evolução morfológica; Área superficial.

1Instituto Nacional de Pesquisas Espaciais - Laboratório Associado de Sensores e Materiais - São José dos Campos (SP) - Brazil Correspondence author: Miguel A. Amaral Jr. - INPE/LAS - Av. dos Astronautas, 1.758, Jd. da Granja - CEP 12.227- 010 - São José dos Campos (SP) - Brazil E-mail: miguel.amara|@las.inpe.br

Received: 02/23/2015 Approved: 06/26/2015 


\section{INTRODUCTION}

Porous silicon (PS) is often generated by electrochemical etching of crystalline silicon in aqueous or non-aqueous electrolytes containing hydrofluoric acid (HF) and addtive ${ }^{(1)}$. Ethanol is one of the most used additive for PS formation because it increases the wettability on the silicon surface generating porous layer with great homogeneity ${ }^{(2)}$.

The interest on PS increased rapidly only after the discovery of its visible photoluminescence (PL) at room temperature ${ }^{(3)}$. However, apart from this important optical property, one of the greatest interest in its application its large surface area and diversity of morphology, originating a promising candidate for applications such as biosensor, gas sensor, solar cells and substrate for film ${ }^{(4-6)}$.

Several reports have shown that the parameters involved in the porous silicon formation process prepared via electrochemical etching have much influence on the characteristics of the resulting layer ${ }^{(7,8)}$. The most important parameters are current density, HF concentration, temperature, etching time, Si type and dopant concentration. In this sense, this work aims to investigate the effect of the etching time and current density on the porous layer. Scanning electron microscopy (SEM) was used to investigate the morphological evolution of the surface and estimate the pore size. In order to calculate the surface area was used an optical profilometer $(\mathrm{OP})$. In this study, the pore size were classified according to the International Union of Pure and Applied Chemistry (IUPAC) as shown in Table 1.

Table 1: Classification of the porous silicon according to the pore size.

\begin{tabular}{c|c|}
\hline Type of porous silicon & Pore size \\
\hline Micropore & $<2$ \\
Mesopore & $2-50$ \\
Macropore & $>50$ \\
\hline
\end{tabular}

\section{EXPERIMENTAL}

PS samples were obtained from n-type silicon wafers of $10 \times 10 \mathrm{~mm}(100)$ orientation, $1-20 \Omega . \mathrm{cm}$ and with indium contact on the backside. The etching solution used was HF (48\%): deionized water: ethanol $(95 \%)=(1: 2: 1)$ in volume. The PS samples were prepared with varying two electrochemical parameters. The first sample set was obtained varying only the electrochemical etching time and the second only the current density. The two set of PS samples are shown on the Table 2.

A Teflon cell was used to prepare the samples (Fig. 1). In this cell, the Si wafer is placed on a metal disk and sealed through an O-ring, so that only the front side of the sample is exposed to the electrolyte. During the electrochemical etching process, the sample was illuminated to supply holes that must be available at the surface.

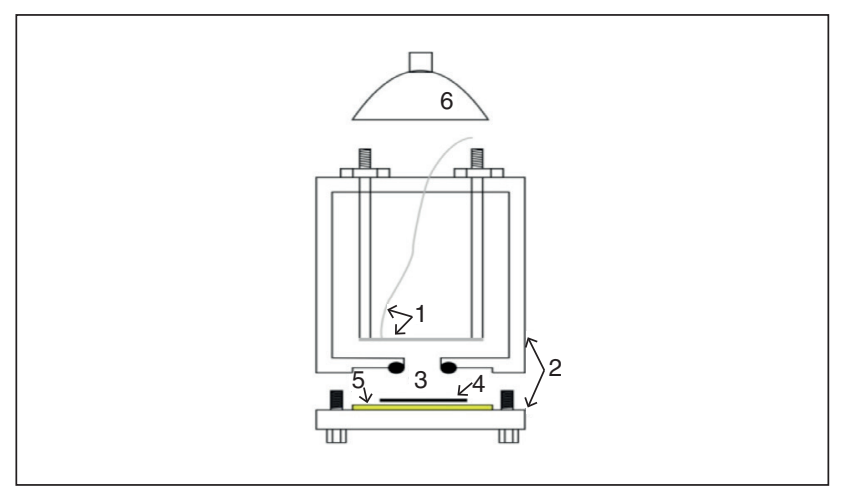

Figure 1: Diagram of the electrolytic cell. (1) Platinum electrode (cathode), (2) Teflon cell body, (3). O-ring, (4) Silicon sample, (5) Contact brass (anode), (6) Lamp support.

\section{RESULTS AND DISCUSSION}

Fig. 2 shows the top view image of a typical PS sample prepared by photoelectrochemical oxidation of n-type silicon, etching at different anodization time from 5 to $30 \mathrm{~min}$ and current density of $75 \mathrm{~mA} / \mathrm{cm}$. In general, there is a continuous evolution in the shape and size of the pores. It was observed that the shape, and the size of macropores are strongly influenced by the anodization time. By comparing the different anodization times it is observed that the superficial structures are more homogeneous as a function of increasing etching time. In Fig. 2(a), for 5 minutes etching time, it is possible to observe the growth of big and small pores, but small in higher amounts. However, the morphologic aspect of both is very similar.

Table 2: Electrochemical Parameters.

\begin{tabular}{|c|c|c|c|c|}
\hline Set of Samples & Time (min) & Current Density $\left(\mathrm{mA} / \mathrm{cm}^{2}\right)$ & Electrolyte (HF/H ${ }_{2} \mathrm{ODI} /$ Ethanol) & Illumination (W) \\
\hline \multirow{5}{*}{ Etching Time } & 5 & 75 & $(1: 2: 1)$ & 50 \\
\hline & 10 & 75 & $(1: 2: 1)$ & 50 \\
\hline & 15 & 75 & $(1: 2: 1)$ & 50 \\
\hline & 20 & 75 & $(1: 2: 1)$ & 50 \\
\hline & 30 & 75 & $(1: 2: 1)$ & 50 \\
\hline \multirow{7}{*}{ Current Density } & 20 & 15 & $(1: 2: 1)$ & 50 \\
\hline & 20 & 30 & $(1: 2: 1)$ & 50 \\
\hline & 20 & 45 & $(1: 2: 1)$ & 50 \\
\hline & 20 & 60 & $(1: 2: 1)$ & 50 \\
\hline & 20 & 75 & $(1: 2: 1)$ & 50 \\
\hline & 20 & 90 & $(1: 2: 1)$ & 50 \\
\hline & 20 & 105 & $(1: 2: 1)$ & 50 \\
\hline
\end{tabular}




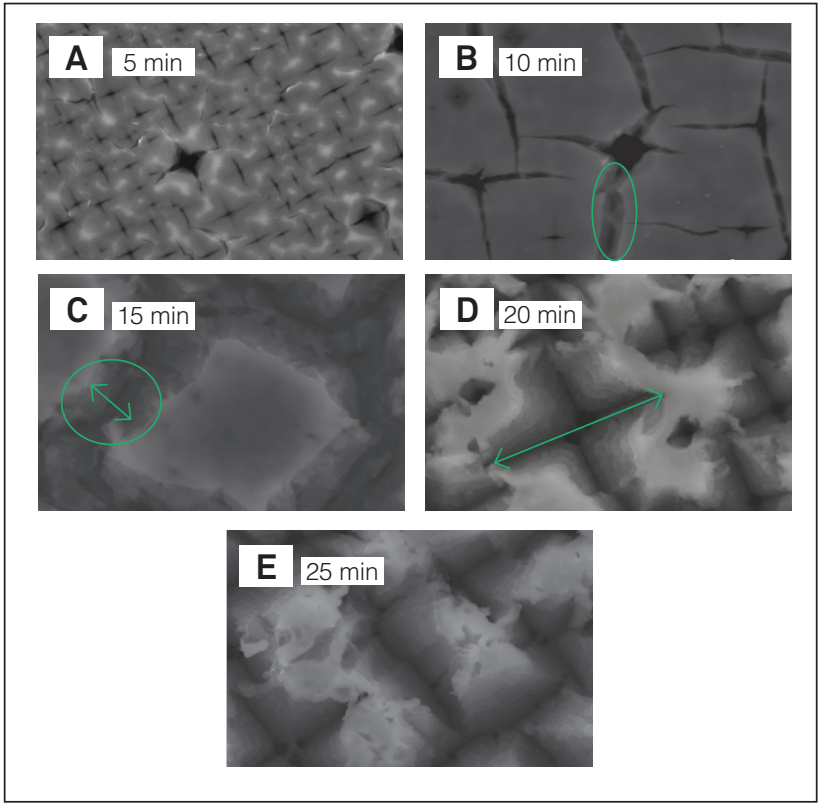

Figure 2: SEM images $(5000 x)$ of Porous Si obtained at different etching time (a) 5, (b) 10, (c) 15, (d) 20 and (e) 30 minutes.

According to Fig. 2(b), for 10 minutes etching time, it is possible to observe the increase of pores, as well as cracks formation. In Fig. 2(c), for 15 minutes etching time, a better definition in the crack originating macropores all over the surface of Si can be observed. For this type of porous layer, the pore size was considered to be the distance between the crystallite involved by the cracks, (distance between the walls) as illustrated by the arrow in Fig. 2(c). In Fig. 2(d) and Fig. 2(e), the porous layer starts to stabilize, and the crystallites start to break due to the increase in the superficial tension. It can be seen that for those times the morphology is similar.

It can be noticed that there is an increase, in the distance, between the crystallites for anodization time varying from 5 to 15 minutes. After 15 minutes, there are no significant changes between the crystallite distances. From these results, we can observe that the application of low current densities for long periods results in homogeneous layers of PS. Other(s) authors like Jeyakumaran, Suriani and Jingmei ${ }^{(9-11)}$ also investigated the parameters to prepare the porous silicon via electrochemical etching and analyzed the porous surface by SEM. Jeyakumaran et al. ${ }^{(9)}$ reported an increase in the PS pore diameter from 2.1 to $3.5 \mu \mathrm{m}$ as the etching time was prolonged from 10 to $20 \mathrm{~min}$. However, longer etching times of 30 and 40 min led some of the pore walls to break, thus exposing a small portion of the next layer. This effect was also observed in this work. Suriani Yaakob et al. ${ }^{(10)}$ related the morphology of the as-prepared PS changed from a narrow columnar structure with side branching at $30 \mathrm{~s}$ to larger, non-branched columns at $300 \mathrm{~s}$. Jingmei et al. ${ }^{(11)}$ reported that pore sizes decreased from about $20 \mathrm{~nm}$ to $10 \mathrm{~nm}$ besides long etching time caused a mergence of the small pores and led to more complex microstructures.

Figure 3 shows the top view image of a typical PS sample prepared by photoelectrochemical oxidation of n-type silicon,

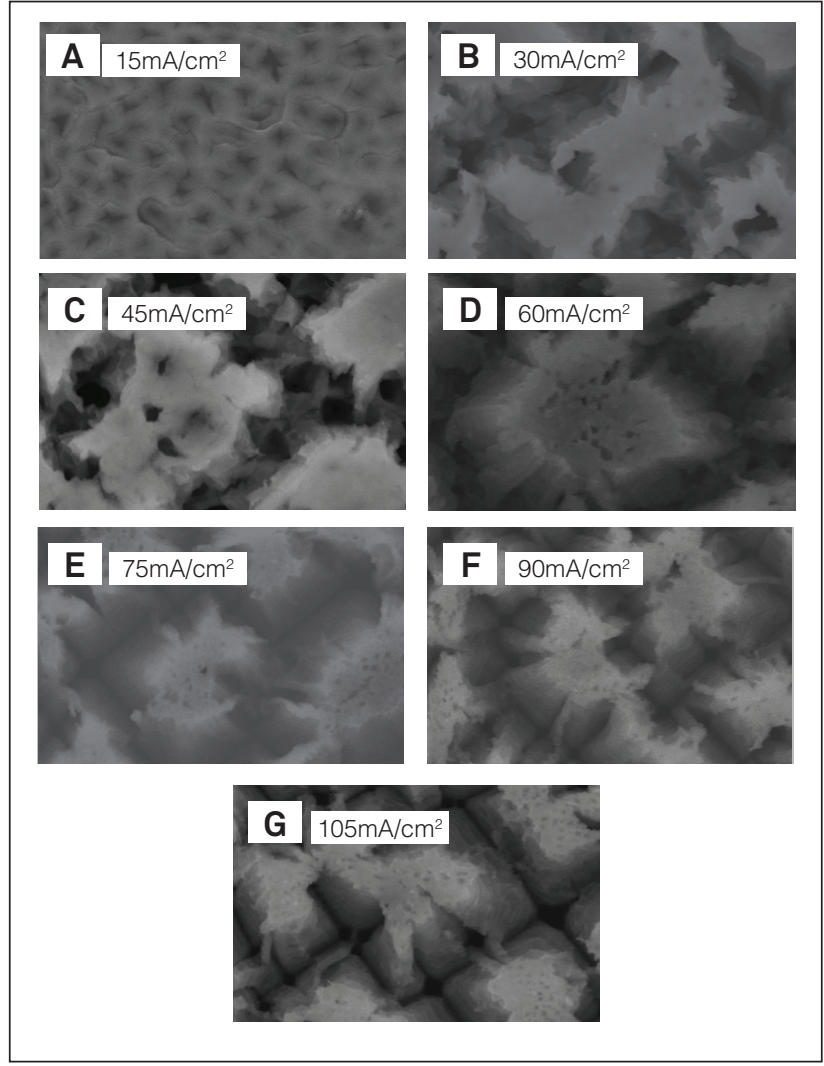

Figure 3: SEM images (5000x) of Porous Si obtained at different current density (a) 15, (b) 30, (c) 45, (d) 60, (e) 75, (f) 90 and (g) $105 \mathrm{~mA} / \mathrm{cm}^{2}$.

etching at different current density from 5 to $105 \mathrm{~mA} / \mathrm{cm}^{2}$ and etching time of $20 \mathrm{~min}$. The etching time was fixed at 20 min because the initiation of a porous layer with homogeneous morphology (Fig. 2d). The current density was evaluated by dividing the value of the current measured by the circular area of the O-ring resulting in the values showed in the Table 2.

By applying a current density of $15 \mathrm{~mA} / \mathrm{cm}^{2}$ (Fig. 3a) was observed at the first apparition of small pores. Throughout the study the morphological evolution as a function of current density, the greatest variation of morphology of the porous layer was between 15 to $30 \mathrm{~mA} / \mathrm{cm}^{2}$. By applying $30 \mathrm{~mA} / \mathrm{cm}^{2}$ (Fig. 3b) appeared a more complex structure, due to the increased current flow and consequently increasing the samples attack. This increase caused a break in the pores and linked them with each other giving rise small cracks. Apparently, the SEM images don't detect a large variation in the pore diameter and also the morphology of the porous layer at current densities above $30 \mathrm{~mA} / \mathrm{cm}$.

Author like Bomin ${ }^{(12)}$ also investigated the current density to prepare the porous silicon via electrochemical etching in solution containing $\mathrm{HF}$ and ethanol in a volumetric proportion of $1: 1$ at fixed etching time of $300 \mathrm{~s}$ and analyzed the porous surface by SEM. Bomin observed pores very stable at the surface morphology of PS obtained with $200 \mathrm{~mA} / \mathrm{cm}^{2}$. However the PS prepared at current density above $300 \mathrm{~mA} / \mathrm{cm}^{2}$ displayed the cracked surface and then collapsed to cracked domains. These results are in 
agreement with this work, despite having used higher current density because it was also used a greater proportion of HF and ethanol.

Through the SEM images was estimated the mean diameter of the pores. For this, was carried out a systematic measurement in several SEM image regions. After the crack of the pores (complex morphologies) was observed a wide range of the pore diameter, which caused the increase in the standard deviation in the measurements. These results can be seen in Fig. 4.

Through OP (Wyko, Modelo NT 1100, Veeco, EUA), it was possible to calculate the surface area of the PS. The OP was connected to the computer by the Wyko Vision 32 (Veeco software, EUA). The measurements were analyzed with a $20 \mathrm{X}$ increase in an area of approximately $6.89 \times 10^{-4} \mathrm{~cm}^{2}$.The measurements were carry out several times in different points and the surface area measured by the OP software can be observed in Fig. 5 .

The results showed that for both samples set, there is an increasing in surface area of PS. This fact is justified by the increase in the amount of pores and its diameter (shown in SEM images), which leads to the irregularities present on the surface. Despite a wide variety pores present in diameter, the surface area obtained by the area showed no large dispersions.

The sample set for varying time showed an increase in surface area of $131 \%$ for 30 minutes and for second sample set the increase was $185 \%$ for current density of $90 \mathrm{~mA} / \mathrm{cm}^{2}$. The results of this

A

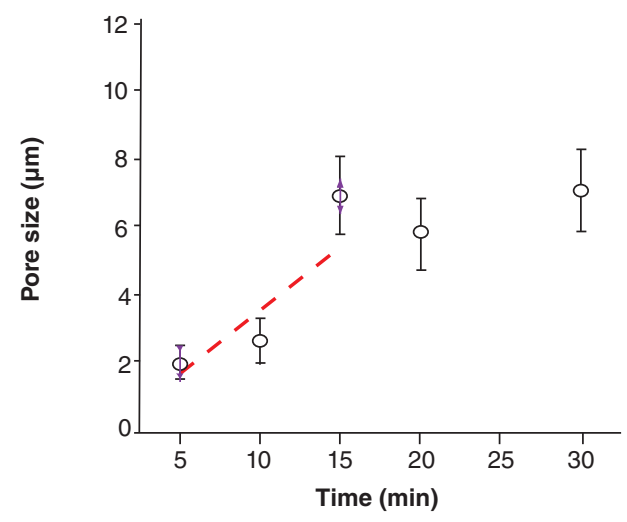

B

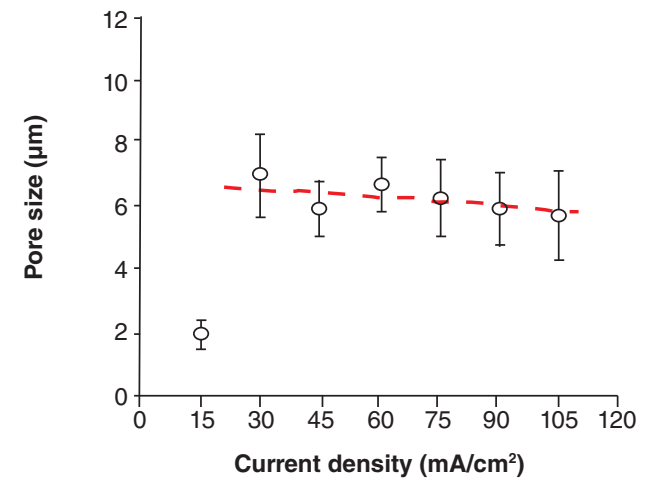

Figure 4: Pores size estimated from SEM images at different (A) Etching times and (B) Current density. study show that it is possible to control the PS surface area and morphology for use in many applications.

\section{CONCLUSIONS}

This study revealed that a PS surface formed by macropores with different shapes and sizes that change with the nature of the electrolyte, anodic current density, type and resistivity of the silicon wafer. From the obtained results, it can be seen that the influence of the etching time and current density is extremely important in the production of PS by electrochemical etching, resulting a significant variation in the structure and in the morphology of the porous layer. It was shown that both the diameter of the pore had an increase due to the increase in the etching time and current density. The morphology of the porous layer had a strong variation until 15 minutes of etching time. The porous layer presented large pores in lower quantities and smaller pores in higher quantities distributed over the surface for a 15 minutes of etching time. The rupture of these pores was evident, thus forming crystallites of micrometric dimensions surrounded by empty spaces, with the 20 to 30 minute etching time. The formation of "star shape" pores has also been observed and a higher homogeneity of the porous layer. For the samples obtained by varying the current density was observed a higher homogeneity in the morphology of their respective surfaces. The minimum current density for porous

A

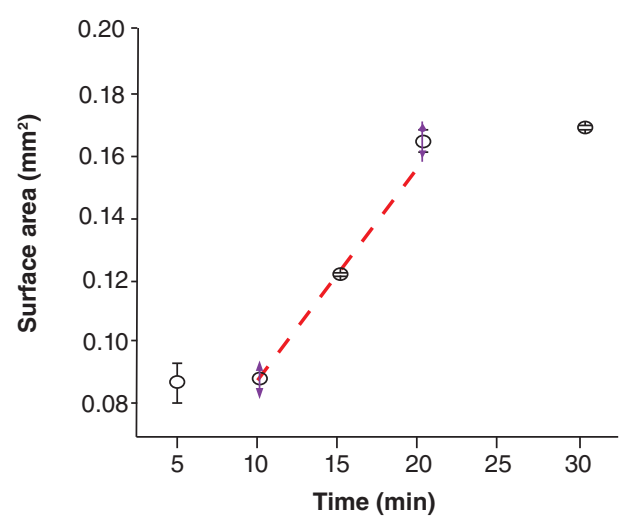

B

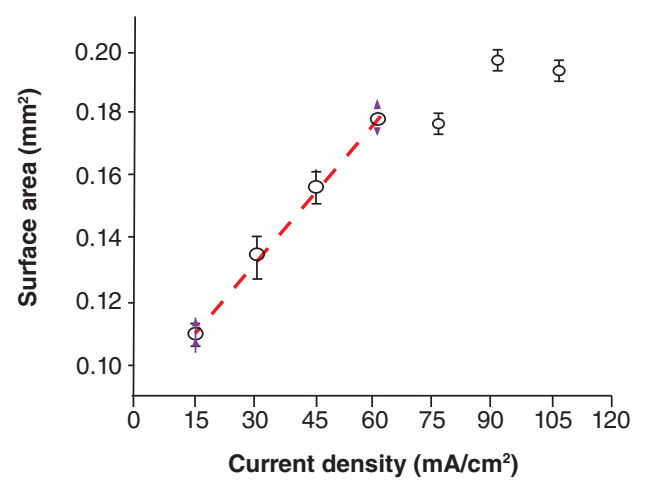

Figure 5: Surface area of the porous layer for different (A) Etching time and (B) Current density. 
silicon formation was $15 \mathrm{~mA} / \mathrm{cm}^{2}$. Below this value, only small spots were observed on the samples, and through the SEM pictures it was not possible to observe pores on the surface of silicon. The SEM images showed that the greatest surface morphological change occurred to values between 15 to $30 \mathrm{~mA} / \mathrm{cm}^{2}$, where the small pores in large quantities are breaks giving rise crack. Above the $30 \mathrm{~mA} / \mathrm{cm}^{2}$, the porous layer morphology does not have large change but the surface area shown increase as function of the current density. These results showed that it was possible to increase the surface area until $185 \%$ and that the etching time influences the stress on the porous layer, and the current density the rate of attack. This article presents important contributions to the study and understanding of the porous silicon formation process by anodizing which may be useful for future applications destined for material requiring high surface area.

\section{REFERENCES}

1. OGATA, Y. H.; KOYAMA, A.; HARRAZ, F. A.; SALEM, M. S.; SAKKA, T., Electrochemistry, 75, 270-272, 2007.

2. MIRANDA, C. R. B., Filmes de Diamante Nanocristalino Infiltrado em Substratos de Silício Poroso Através das Técnicas CVD/ CVI. 2009. 192f. Tese (Doutorado em Engenharia e Tecnologia Espaciais/ Ciência e Tecnologia de Materiais e Sensores). Instituto Nacional de Pesquisas Espaciais, São José dos Campos, 2009.
3. CANHAM, L. T., Appl. Phys. Lett, 57, 1046, 1990

4. HARRAZ, F. A.; ISMAIL, A. A.; BOUZID, H.; AL-SAYARI, S. A., Ap. Surf. Science, 307, 704-711, 2004

5. ASMIET, R.; WISAM, J. A.; HASSAN, Z.; KHALID, O.; IBRAHIM, K., Optik, 122, 2075-2077, 2011

6. SILVA L. M.; SANTOS M.; AZEVEDO A. F.; BALDAN M. R.; FERREIRA N. G., Materials Science Forum, 802, 158-162, 2014.

7. SMITH, R. L.; COLLINS, S. D., Porous Silicon formation mechanisms, J. Appl. Phys. 71, R14, 1992.

8. BALAGUROV, L. A. et al, Electrochim Acta 51, 2938-2941, 2006.

9. JEYAKUMARAN, N.; NATARAJAN, B.; RAMAMMURTHY, S.; VASU, V., Structural and optical properties of n-type porous silicon-effect of etching time. Inter. J. Nanosci. Nanotech., 3(1), 45-51, 2007.

10. YAAKOB, S.; ABU, M. B.; ISMAIL, J.; HANA, N. H. A. B.; IBRAHIM, K., The Formation and Morphology of Highly Doped N-type Porous Silicon: Effect of Short Etching Time at High Current Density and Evidence Of Simultaneous Chemical and Electrochemical Dissolutions. Journal of Physical Science, 23(2), 17-31, 2012.

11. JINGMEI L.; XUAN C., Effect of Etching Time on Porous Silicon Formation, 11, 9-7,2008.

12. $\mathrm{CHO}$, B.; JIN, S.; LEE, B.; HWANG, M.; KIM, H.; SOHN, H., Investigation of photoluminescence efficiencu of $\mathrm{n}$-type porous silicon by controlling of etching times and applied current densities. v89, p92-96, 2012. 